\title{
Symbols of the Songs by Leela Benare in Vijay Tendulkar's Play Silence! The Court is in Session
}

\author{
Ramen Goswami Sirjii \\ Research Scholar \\ Magadh University \\ English Department \\ Bankura, West Bengal, India \\ mtalib282@gmail.com
}

Abstract

The current study explores and sheds light on the trials and tribulations of an independent Women, Miss. Leela Benare, in Vijay Tendulkar's play Silence! The Court is in session. Here Tendulkar dwells on gender Discriminations. Till the commencement of the mock-trial, Benare is the most cheerful, talkative Character. She makes comments on her own independent life, on the behaviour of her fellow actors, she Sings and shows her vitality and assertiveness even in the second act when the mock trial with her as the Accused begins. In this context her songs are relevant to the structural design of the play as well as these Highlight the mental agony and pangs of a deep rooted mother. In Silence! The Court is in Session, though the dialogues of the characters are set in unvarnished prosaic terms, four songs and one poem have been used in order to add lyrical flavour to unvarnished language of reality. Tendulkar has these songs sung by Benare, the protagonist of the play, not by other characters. A song is no doubt a lyric that expresses a set of emotion, feeling and ideas and thereby exposes the psychic life of the speaker. The four songs in the play, of which two are derivative and the other two are composed by the dramatist, are set in Benare's mouth in order to equip the woman with the right to narrate her life in lyrical terms.

Keywords: patriarchal society; Male domination; marriage: motherhood; experience; pangs. 
Introduction:

In the play Silence! The court is in Session, though the conversation of the characters is set in simple prosaic terms, four songs and a poem is used in order to add lyrical taste and to present the hazardous condition of a girl in this patriarchal society. Tendulkar has these songs sung by Benare, the protagonist of the play, not by any other character in order to express the mental turmoil of a helpless girl in this society of male chauvinism. In this way the society is responsible for the violation of our age- old dictum ' Nari tame Narayani'(Manu Smriti).

At the age of thirty four, Benare recalls her first love affair with her own maternal uncle in this song which she croons in front of Samant:

“Oh, I've got a sweetheart Who carries all my books, He plays in my doll' s house And says he likes my looks I tell you a secret----

He wants to marry me.

But mummy says, I am too little To have such thoughts as these" (5)

In this song, Benare reveals, when she was 14, she fell in love with her uncle. Her uncle was the only man who came in her life at the time of puberty or teens. He first praises her youthful beauty. She has also fallen in love with her. When their love was about to consummate in marriage, Benare's mother was the first obstacle in this decision, who disarmed Benare from this marriage. According to her, being a girl of tender age should think of marriage. She tried to free herself from this gross reality by committing suicide, but her body did not die. The implication of this song is that had her mother not stood in their lively life and had her brave man not ' turned tail and ran away'; she would not found herself in such a condition.

Benare's second song is a nursery rhyme with which she was accustomed with during her school days: "The grass is green

The rose is read This book is mine Till I am dead". (9) 
This song denotes possessive power and freedom. Naturally, both the 'grass' and ' rose' display their natural characteristics. Benare's life in the same way may compare with a ' book' can not possessed by anyone else. As an educated modern girl, Benare, devoid herself from the beaten track of the male dominated society and establishes her personal freedom, free thought by reading of books after books She has read Mrs. Sirish Pai' s poem which she recites in front of her coactors. The poem focuses on the defeat of woman in this male dominated society. Benare is such a type of strong rooted tree that can not be destroyed by any hurdles of society. Her lively attitudes leads her into a position of unstoppable vivacity, innocence and last but not the least a much more vivacious lady ( but throngs of pangs are inside into her heart).

The poem is:

"Our feet tread on upon an unknown

And dangerous pathways evermore

Wave after blinded wave is shattered Stormily upon the shore

Light glows alive again . Again It mingles with the dark of night.

Our earthen hands burn out, and then

Again in flames they are alight Everything is fully known,

And everything is clear to see.

And the wound that's born to bleed Bleeds on for ever, faithfully.

There is a battle sometimes, where Defeat is destined as the end

Some experiences are meant

To taste, then just to waste and spend...." (10)

In this male dominated world woman had to plunged on an unknown path where she come across a life of turmoil, mixed with hope and despair. Experiences are like waves come with one after another in shores of life as hopes or as frustration. Fed up with this problem bound life she tries to control it with her own choice. She continues her struggle for having a free life. With full 
knowledge of loss and defeat she carries on her fight for having the experience of battle. Benare's longing for motherhood and wifehood get reflected on the next song which she sings in front of other co- mates:

“An old man from Malad came up to the fireside... An old man from Malad, the old man' s wife , the wife' s little baby, nurse, the nurses visitors.....”. (10)

Benare is stooped down by her own past affairs. She might have loved some unmarried man. Instead she loved a man having a wife of five children. Her loss in the past in love affair led her to love not the body of that married person, instead she loved her intellect. Actually, in alter of love Benare's body is the representation of offerings. The body might have betrayed her but for the same body she experienced sexual bliss. After the mock trial her co- mates are pretend to be innocent and try to make her forgot all about the trial and the verdict of mock- law courts. In the last lullaby the crow's role is significantly mentioned: "The parrot to the sparrow said

Why, o why, are your eyes so red? Oh, my dear friend what shall I say? Someone has stolen my nest away

Sparrow, Sparrow, poor little sparrow

'Oh brother crow oh brother crow.. Sparrow.” (78)

On being supported by Samant, Benare seems to have dream of becoming a mother. On that dream vision she tells the living parrot, which seem to symbolise her son, about the destructive role of the crow. It is the crow that had destroyed her nest although it pretends to be an innocent person. In this contest we must memorize the famous lines of Helen Cixous: " The voice in each woman is not only her own, but spring from the deepest layers of her psyche."(The Laugh of Medusa).

At thirty-four Benare retrieves the past love affair she had with her own maternal uncle in this song which she croons to herself in front of Samant: "Oh, I've got a sweetheart... To have such thoughts as these". In this song, Benare reveals her love secret. At fourteen, she fell in love with her uncle. He was the only man who came in her life at her teens. He gave recognition to her growing 
youth. She also reciprocated love with him. At that age it was not known to the tender girl whether their love would be tabooed by social norms and mores. So, when their love was about to consummate in marriage, her mother disarmed her move towards marriage, saying that she, being a girl of tender age, should not think of marriage. Benare tried to liberate herself from the societal domination by committing suicide, but her body did not die. In her last monologue she confesses that she was then wrong in her attempt at suicide. She should have then smashed the face of her brave man, who turned tail and ran away, and spit on his smashed face, instead of her attempt at suicide.

Her second song is composed of some nursery rhymes which he internalized during her school days: "The grass is green...Till I am dead". At school she internalized the ideology of enlighten which emphasizes personal freedom based on reason. The song is woven with the logic of possessive power. As in nature the grass and rose display their own character through some unchanged shades of hue, her life which she considers as a book can not be possessed by any one else. Her sense of personal freedom has come to be developed from her reading of books after books. The western education seems to have left indelible impression of personal liberty in her mind. This is why she is fond of leading life on her own terms.

She failed in love at her adolescence. There after she has read Mrs. Sirish Pai's poem which she recites in front of her colleagues. The poem focuses on the ubiquitous defeat in woman's life. Inspite of her awareness of this defeat, Benare struggles to lead her love life on her own terms in opposition to conventional way of life-- "Our feet tread on upon unknown.../To taste...spend...". In the androcentric world the woman is plunged on an unknown dangerous path where she comes across a life of turbulence mixed with hope and despair. Her hopes and desires are burnt out with a deep wound in her heart to bleed. Enlightened Benare was not unware of woman's precariousness in male-dominated society, yet she wages the battle for her motherhood and home in an unconventional way. 
Benare's urges for wifehood and motherhood get reflected in the song --." An old man from Malad...nurse's visitors". She was not cowed down by the failure of her past love life. She might have loved some unmarried young man. But she led her life in the quite opposite direction. She loved a man having a wife and five children. She loved not his body but his intellect. Out of deep love for him she worshipped him as a God, but he accepted her body.

A portion of a song was sung by Benare at the end of Act I, but it was completed at the end of the play. At that time, she did not project the cruel role of the crow. The last lullaby seems to be taking in Benare's dream. On being backed by Samant, Benare seems to have a dream of becoming a mother. In dream, she tells the living parrot, which seems to symbolize her son, about the destructive role of the crow. It is the crow that has destroyed her nest, yet it pretends to be innocent about it. Even it denies having to do with the troubles of the sparrow's life. Helen Cixous opines, "The voice in each woman, moreover, is not only her own, but springs from the deepest layers of her psyche, her own speech becomes the echo of the primeval song once she heard..." Tendulkar suggests the presence of impurity in the sacrosanct structure of Indian polity through the inclusion of the crow in it. "No matter how plain a women may be,if truth and honesty are written across her face she will be beautiful" -Eleanor Roosevelt (her essayes).

\section{Works Cited:}

Silence The Court is in Session- Oxford University Press, publishing 1978

Silence The Court is in Session -Ray Book Concern,2 Shyama Charan De Street, publishing2009 